\title{
Chinese Stated-owned Oil Companies in the U.S.
}

\author{
Shiwei Jiang ${ }^{1}$ \\ ${ }^{1}$ Old Dominion University \\ Email: sxjiang@odu.edu
}

\begin{abstract}
This article examines the cases of Chinese state-owned oil companies in the U.S., including PetroChina, Sinopec and China National Offshore Oil Corporation (CNOOC). The author provides novel explanations why they failed in the U.S. market. With detailed analyses, the author comes to conclude that the failures of Chinese state-owned oil companies were caused by three major barriers, including CFIUS, Anti-China interest groups of U.S. Congress and the cultural differences between relation-based society and rule-based society.
\end{abstract}

Keywords: Chinese state companies, U.S. market, oil industry

\section{Introduction}

With a large amount of foreign reserves, the Chinese government is encouraging Chinese companies to speed up their internationalization and purchase overseas assets, especially oil assets. There are three major state-owned companies in China: PetroChina, Sinopec, and China National Offshore Oil Corporation (CNOOC), which are called the "Big Three." Their success at entering those markets in developing countries is chiefly based on three strategies: first, to choose the place where Western oil companies are not willing to enter because of high risk and instability; second, to help build local infrastructure; and third, to provide financial aids to oil-rich developing countries. ${ }^{2}$ However, these strategies do not apply to Chinese oil companies' business in the U.S.

In the past, when it came to oil and security, scholars have focused on the Middle East oil trade, terrorists and security issues. There was a sea of literatures and studies on the Middle East and oil. ${ }^{3}$ By contrast, the studies of China-U.S. oil trade were few. Despite the fact that China-U.S. trade is increasing and China-U.S. relations are improving, the two countries are still cautious about each other's investment in some sensitive sectors, such as oil and telecommunications.

In this article, I will address why and how China's state-owned oil companies (CSOOC) have failed in the U.S. market. First, many American readers may wonder what are the rankings of CSOOC in international business? And, how does the Chinese government influence CSOOC? An overview of CSOOC answers the two basic questions at the beginning. Second, after the overview, I examine the big three CSOOC in details. I find that their results are different in the U.S. PetroChina faced a lawsuit from American investors. Sinopec was forced to terminate three agreements in Wyoming. CNOOC received investigations from the Committee on Foreign Investment in the U.S. (CFIUS) which led to its failure to purchase the U.S. oil firm - Unocal. Third, admittedly, their failures in the U.S. market were due to complex factors (e.g., political interventions, America's strict environment protection, different cultures and more); however, I need to boil them down to some key factors relevant to international political economy. These key political-economic factors are categorized into three aspects: the U.S. government (CFIUS and the interaction between anti-China interest groups and U.S. Congress), the company itself (weaknesses of CSOOC), and the Chinese government (its rising military power makes it more difficult for Chinese companies to purchase oil assets in the U.S.).

China's three big oil companies are all state-owned enterprises; thus they have some advantages that their Western counterparts do not have. According to the 2010 American magazine, Fortune,

\footnotetext{
${ }^{1}$ Changxin Gao, "Big Three Oil Companies See Earnings Fall", China Daily, March 26, 2013.

${ }^{2}$ Ian Taylor, "China's Oil Diplomacy in Africa", International Affairs, Volume 82, Issue 5, 2006.

${ }^{3}$ For example, Steve Yetiv's two books, Crude Awakenings: Global Oil Security and American Foreign Policy and The Petroleum Triangle: Oil, Globalization, and Terror.
} 
PetroChina and Sinopec were listed as the 7th and 10th of the Global 500, respectively. ${ }^{4}$ In terms of market value, their rankings are even higher. PetroChina was ranked the first by Financial Times Global 500. ${ }^{5}$ Although CNOOC was listed as the 252th in 2010, it is growing very fast (it was ranked 318th in 2009). PetroChina and Sinopec always occupy the first and second place of the China's top 500 enterprises, respectively. According to Ping Deng, by the end of 2004, "Of the top 500 Chinese firms the dominant source of Chinese outward FDI - only one is privately owned and 25 are collectives, which are usually owned by county and municipal government; the rest are state-owned enterprises (SOEs)." 6

The energy sector is the priority of Chinese government's international investment. Actually, a majority of Chinese government's overseas investment was directly or indirectly operated by the big three Chinese national oil companies. Over the past decade, China has boldly used billions of its foreign reserves (mostly U.S. dollars) to invest in oil-rich countries, including some dangerous places like Afghanistan, Iraq and Libya. With strong political support from the state government, the three oil companies have gained tremendous benefits globally. In Africa, PetroChina and Sinopec are prestigious companies because African businessmen and politicians know that the Chinese national oil companies are backed up by the Chinese central government. For this reason, their financial condition is very stable and will not have the capital shortage that some Western companies might have. Today, thousands of young Chinese college graduates are competing fiercely for jobs in those state-owned oil companies.

Although the Chinese oil companies have gained a certain degree of autonomy from the Chinese government in recent years, they are still under the great influence of state-controlled bureaucracy. First, the development of Chinese state-owned companies is driven by officials' promotion instead of profitsmaking, because the primary instrument of power that the party-state exercises over China's stateowned oil companies is the power to appoint, dismiss, and promote the companies' general managers. ${ }^{7}$ Second, their large investment projects must get approval from the National Development and Reform Committee (NDRC). In addition, their oil prices are also regulated by NDRC. Third, as they are stateowned companies, a large part of their revenues will be taxed by the government or be turned over to the state treasury.

In 2013, China's new president Xi vowed to crack down on both "tigers and flies" - powerful leaders and lowly bureaucrats - in his campaign against corruption ${ }^{8}$ Afterwards, a series of investigations have been carried out. In early 2014, Chinese state media exposed PetroChina and Sinopec's domestic and foreign corruption. For example, Jiemin Jiang, the head of NDRC who oversaw state-owned companies was under investigation for "severe disciplinary violations." ${ }^{9}$ Before he became the head of NDRC, Jiemin Jiang was leading, PetroChina, China's largest oil company and also the most profitable one. Jiang received expensive gifts and a large amount of cash when he was in charge of PetroChina. Jiang's downfall showed that there was a great intersection of senior Chinese leaders' private interests and the state-owned companies. Jiang's downfall also exposed the non-transparency of Chinese government's decision-making and thus caused PetroChina to face a lawsuit in the U.S.

\section{$2 \quad$ PetroChina}

\subsection{A. Expansion in Africa versus Lawsuit in America}

PetroChina is the largest state-owned oil company in China. On its official website, it says "It is not

\footnotetext{
${ }^{4}$ http://money.cnn.com/magazines/fortune/global500/2010/

${ }^{5}$ http://en.wikipedia.org/wiki/List_of_corporations_by_market_capitalization

${ }^{6}$ Ping Deng, "Outward Investment by Chinese MNCs: Motivations and Implications", Business Horizons, June 2004.

${ }^{7}$ Erica S. Downs, "Who's Afraid of China's Oil Companies", in Energy Security edited by Carlos Pascual and Jonathan Elkind (Brookings Institution Press, 2010).

8 Tania Branigan, "Xi Jinping Vows to Fight 'Tigers' and 'Flies' in Anti-corruption Drive", The Guardian, January 22, 2013.

${ }^{9}$ Jeremy Page, Wayne Ma and Brian Spegele, "China Probes Former Oil Company Head", The Wall Street Journal, September 1, 2013.
} 
only one of the companies with the biggest sales revenue in China, but also one of the largest oil companies in the world." ${ }^{10}$ Since the mid-1980s, PetroChina started to explore rich reserves of oil fields, especially in the Tarim basin in Xinjiang, China. In the 1990s, it began oversea expansion in the efforts to achieve its goal at that time: become a multinational company as soon as possible. PetroChina has two different experiences in Africa and the U.S. In Africa, it has expanded its business and purchased large oil fields. In the U.S., it has faced lawsuits. In 1997, PetroChina defeated other international oil companies and won the exploitation rights of Muglad basin in Sudan. This is the first time that PetroChina successfully bid the large-scale overseas oil and gas exploration project. ${ }^{11}$ To some extent, Sudan is the point when PetroChina started its global competition.

Many African countries are developing countries rich in natural resources. Their laws regarding anticorruption and exploiting natural resources are not strict, or may lack enforcement. Moreover, China did not have a law like the American Anti-Corruption Act which can investigate Chinese companies' briberies overseas. Some corruption arose from China-Africa oil business and was occasionally reported by Western media. For example:

At Chinese-run mines in Zambia's copper belt they must work for two years before they get safety helmets. Ventilation below ground is poor and deadly accidents occur almost daily. To avoid censure, Chinese managers bribe union bosses and take them on "study tours" to massage parlours in China. Obstructionist shop stewards are sacked and workers who assemble in groups are violently dispersed. When cases end up in court, witnesses are intimidated. ${ }^{12}$

Chinese oil companies' bribery strategy works in Africa, but does not work in the U.S. I observe that there are still some Americans complaining about corruption in the U.S. There might be more corruption in the U.S. than in some Northern European countries. ${ }^{13}$ However, compared to China and most African countries, the U.S. government officials seem free of corruption.

Unlike in Africa where PetroChina has purchased large oil fields and employed thousands of workers, in the U.S. PetroChina has just set up an office in Houston, Texas, where the number of employees just reached over 50 in 2013. In Africa, PetroChina is doing upstream operations (exploiting oil fields), while in the U.S. PetroChina is doing mostly midstream work (transportation and storage of refined petroleum products). ${ }^{14}$ According to Shaolin Li, president of PetroChina International America Inc, in the U.S. they basically buy petroleum products at Point A, move them to Point B and do some processing for added value, and then move them to Point $\mathrm{C}$ to sell. ${ }^{15}$

PetroChina's expansion in the U.S. is not as successful as that in Africa. For example, in 2013, Pomerantz, a New York-based law firm, filed a class action against PetroChina. Several top leaders of PetroChina were involved in corruption and were investigated by the Chinese government. PetroChina's stock share value dropped due to the corruption scandal. But, PetroChina did not report this immediately to its U.S. investors. So, there were some losses to American investors who thought PetroChina's financial statements were false and misleading. They accused PetroChina of "failing to disclose a corruption scandal that has tainted the company and led to the downfall of several senior executives." 16

In addition, Jiemin Jiang, former PetroChina chairman, Jiping Zhou, PetroChina's current chairman, former CFO Mingchun Zhou and current CFO Yibo Yu were accused of violations of the securities laws of the U.S. ${ }^{17}$ Later, PetroChina said it would "vigorously contest the complaint to protect its rights and

\footnotetext{
${ }^{10}$ http://www.petrochina.com.cn/Ptr/About_PetroChina/Company_Profile/default.htm

${ }^{11}$ An Official Report: "Review of 15 Years of Sino-Sudanese Petroleum Cooperation", China National Petroleum Corporation, 2009.

12 "Trying to pull together: Africans are asking whether China is making their lunch or eating it", The Economist, April 20, 2011.

${ }^{13}$ Denmark, Finland, Sweden and Norway are among top 5 in the Corruption Perceptions Index 2013 by Transparency International. The U.S. is ranked 19.

${ }^{14}$ The oil industry is divided into three major sectors: upstream, midstream and downstream. For more information, please refer to http://www.psac.ca/business/industry-overview/, accessed on April 16, 2014.

${ }^{15}$ May Zhou: "PetroChina poised for expansion", China Daily USA, November 22, 2013.

16 "PetroChina Sued in US Over Failure to Disclose Corruption", Caijing, September 4, 2013.

17 "PetroChina sued in US court", Xinhua, November 27, 2013.
} 
interests. ${ }^{18}$ Currently, there is no much information about this incident, because the lawsuit is still ongoing and will probably continue for two to four years. ${ }^{19}$ However, according to a Chinese news report, PetroChina is very likely to lose the lawsuit and pay high attorney fees and compensation. ${ }^{20}$ This failure may thwart PetroChina's expansion in the U.S. market.

In China, private business or individuals do not often file lawsuits against the government or those giant state-owned companies, because they know it is very difficult to win lawsuits against government or state-owned companies and get fair compensation. In the U.S., filing a civil or business lawsuit is much more common than in China. In addition, there are more detailed categories of courts in the U.S., such as traffic court, civil court, and small claims court. In the U.S., lawyers and doctors are generally viewed as admired jobs, whereas in China millions of college students are taking exams for jobs of "Gong Wu Yuan" (government employees). Either for lawsuit filing or job-seeking, many Chinese still believe that "Guan Xi" (personal connection/relationship) is more important than rules. Shaomin Li argued that in China the governance environment is based on private enforcement that can efficiently regulate market and resolve disputes and thus China is a "relation-based society". By contrast, the U.S. is a "rule-based society," in which firms and individuals primarily rely on laws to resolve disputes and enforce rights and contracts. ${ }^{21}$ So, when contemplating U.S. market entry, Chinese companies need to perform due diligence on the rule-based environment in the U.S. ${ }^{22}$ The U.S. regulations regarding foreign investment are evolving.

\section{Sinopec}

\subsection{A. The "Going-out" Campaign}

In 1998, with the restructuring of state-owned companies, Chinese oil companies expanded their business to almost every aspect of the oil industry, including oil field exploration, drilling, oil refining, and transportation. Moreover, the 1998 reform of state-owned companies also stimulated Chinese oil companies to pursue oil fields globally. From then on, the domestic and foreign sales of Sinopec have tripled. In recent years, Sinopec is implementing the "going-out" strategy. ${ }^{23}$

Although Sinopec started its overseas expansion later than PetroChina, it is catching up very quickly. In 2001, Sinopec established Sinopec International Petroleum Exploration and Production Corporation (SIPC). Afterwards, Sinopec adopted the strategy of "going out". The going-out strategy is part of China's international petroleum policy, which was proposed by the State Development Planning Commission (NDRC) in 2003. According to China's Jingji (Economic Daily), the NDRC put forward six strategies to protect the country's oil security, which are as follows: ${ }^{24}$

1. To implement the going-out strategy;

2. To carry out the diversification strategy;

3. To build globally competitive flagship oil companies;

4. To conduct petroleum diplomacy;

5. To build domestic oil tanker fleet and expand the Chinese Air Force and the Chinese Navy; and

6 . To set up national petroleum investment funds.

18 "PetroChina says to contest class action suit in U.S. court", Reuters, September 6, 2013.

${ }^{19}$ http://money.163.com/13/0906/13/983HRD1U00251LK6.html, accessed on April 20, 2014.

20 http://finance.china.com.cn/industry/hotnews/20130908/1795770.shtml, accessed on April 20, 2014.

${ }^{21}$ Shaomin Li, Managing International Business in Relation-Based versus Rule-Based Countries: (Business Expert Press, 2009).

${ }^{22}$ Clarence Kwan, Karl P. Sauvant, "Managing International Business in Relation-Based versus Rule-Based Countries", U.S. Chinese Services Group, October 2008.

${ }^{23}$ Numerous studies are on the "going out" strategy of Chinese companies, such as, F Leverett "s "Managing ChinaUS energy competition in the Middle East" (2005) and "The New Axis of Oil" (2006), C Alden's "Harmony and Discord in China's Africa Strategy: Some Implications for Foreign Policy", The China Quarterly, 2009 , Cambridge University Press, WS Chen 's China's Oil Strategy:"Going Out" to Iran, Asian Politics EJ Policy, 2010, H Zhao's "China's oil venture in Africa", East Asia, 2007 and etc.

${ }^{24}$ Bo Kong, China's International Petroleum Policy (Greenwood Publishing Group, 2010). 
Under the international petroleum policy drafted by NDRC, in 2004 Sinopec signed an evaluation deal with Gabon. In the same year, former Chinese President Hu paid a visit to Gabon and signed a series of bilateral trade treaties with his Gabonese counterpart, Omar Bongo, including" a "memorandum of agreement aimed at showing the parties' desire to develop exploration, exploitation, and refining and export activities of oil products." ${ }^{25}$ In 2006, China announced that it would loan $\$ 2$ billion to Angola and build a joint venture between Sonangol Refineries (Sonangref) and Sinopec. ${ }^{26}$ The same as PetroChina, Sinopec also has great interest in Sudan. "In November 2005, Sinopec Group announced plans to partner with PetroChina to purchase an oil field in Sudan, and has reportedly indicated an interest in expanding its business in Sudan." ${ }^{27}$

The early road map of Sinopec's going-out campaign has covered almost every continent except North America. ${ }^{28}$ There are at least three explanatory factors. First, the U.S. is not willing to exploit its own oil, so it is very difficult for Chinese companies to get oil from the U.S. During one speech, Obama said "With only $2 \%$ of the world's oil reserves, we can't just drill our way to lower gas prices." However, many Chinese believed that the oil reserves in the U.S. were underestimated. They also argued that Americans are just smart and do not use their own oils. ${ }^{29}$ In addition, as a rule-bassed country, the U.S. has a series of U.S. environment laws (e.g. Clean Air Act, Comprehensive Environmental Response, Compensation and Liability Act). For example, in 2011, U.S. Environmental Protection Agency (EPA) forced Shell to give up oil drilling plans in the Arctic Ocean off the northern coast of Alaska. ${ }^{30}$

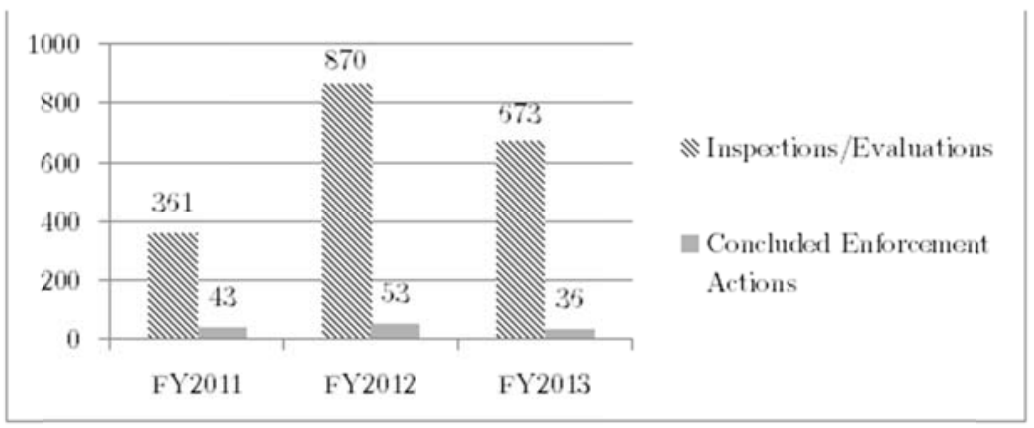

Source: U.S. Environmental Protection Agency (EPA)

Figure 1. Annual number of EPA energy extraction inspections/evaluations and concluded enforcement actions

EPA updates some statistics on its enforcement website ever fiscal year. Figure 1 shows that from fiscal year 2011 through fiscal year 2013, it conducted 1,904 energy extraction inspections and compliance evaluations. However, only 132 cases have been concluded, which accounted for less than 7\% of the total cases. ${ }^{31}$ The enforcement actions have included companies operating gas plants, compressor stations, and oil and gas production facilities in several of the most active U.S. onshore oil and gas plays. ${ }^{32}$ Many cases will be ongoing for years, because the review and investigation process is slow. How much will it cost to resolve? This definitely varies based on multiple factors such as the severity of the

\footnotetext{
25 "Sinopec signs evolution deal for three oil blacks in Gabon", People's Daily, February 4, 2004.

26 "China in Africa: The Role of China's Financial Institutions", African Growing Enterprises File, Institute of Developing Economies and Japan External Trade Organization.

27 "Statement of Sinopec Divestment", Harvard Gazette Archives, March 23, 2006.

${ }^{28}$ Bo Kong, China's International Petroleum Policy (Greenwood Publishing Group, 2010).

${ }^{29}$ http://club.china.com/data/thread/1011/2286/79/92/6_1.html

${ }^{30}$ Dan Springer: "Energy in America: EPA Rules Force Shell to Abandon Oil Drilling Plans", Fox News, April 25, 2011.

31 "National Enforcement Initiative: Ensuring Energy Extraction Activities Comply with Environmental Laws", EPA, 2014.

${ }^{32}$ Georgette Reeves, "Heads Up for Oil and Gas Companies Regarding EPA's National Enforcement Initiative", Trinity Consultants, May 28, 2013.
} 
damages, the violators' attitudes, legal defense and more. According to EPA's annual trends analysis for fiscal year 2013, EPA assessed more than in $\$ 1,000$ million administrative and civil judicial penalties, a big increase from 2012 (\$200 million). ${ }^{33}$ Indeed, the time and cost-consuming process of investigation from EPA set up high entry barriers for Chinese oil companies to invest in the upstream oil sector in the U.S. (exploration and production).

Second, high labor costs and strict immigration system have reduced Sinopec's motivation to invest boldly in the U.S. According to the Bureau of Labor Statistics, in 2009 China's average hourly compensation costs were only $\$ 1.74$, which was far behind the U.S. ${ }^{34}$ Moreover, the strict immigration system in the U.S. has basically ruled out low-skilled cheap Chinese laborers. Hiring foreign workers in the U.S. is a time-consuming process, because United States Citizenship and Immigration Services (USCIS) require the wage and education degree to meet certain criteria. Besides, the employer has to pay high fees to an immigration lawyer for filing legal paperwork. By contrast, there are fewer visa restrictions in Africa. Chinese oil companies can easily hire thousands of cheap Chinese workers and then send them to those oil fields in Africa, which is quite impossible in the U.S.

Third, previous failures of Chinese companies in the U.S. hampered Sinopec's going-out campaign in the U.S. As discussed in the next section, in 2005, CNOOC, another Chinese oil company, bid high but failed to purchase Unocal, an American oil company. CNOOC spent over $\$ 2.2$ million on hiring American lobbying firms for the purchase of Unocal, but finally gained nothing. ${ }^{35}$ Chengyu Fu, chairman of CNOOC, was then very disappointed by the result. He argued that CNOOC's failure in the U.S. was largely due to the U.S. government intervention and the lack of mutual political trust between China and the U.S., which might hurt other Chinese investors' confidence in investing the U.S. market and generated lasting negative feelings in both countries. ${ }^{36}$

B. Sinopec: Three Agreements Terminated in Medicine Bow, Wyoming

In 2012, Sinopec Engineering Group (SEG), a subsidiary of Sinopec, signed three agreements with Fuel \& Power LLC of Medicine Bow, Wyoming, to build an advanced coal-to-gasoline plant. Medicine Bow is a very small town with population less than 300 and is probably unknown to most Americans. Sinopec was selected to build the plant because "Sinopec brings to the potentially expensive and complicated project less pricey Chinese components and materials. It may also open up the doors to attractive Chinese capital" according to the Wall Street Journal. ${ }^{37}$ Chinese media also reported this and praised Sinopec for further opening the U.S. market. Some Chinese scholars were optimistic about Sinopec's move in the U.S. Boqiang Lin, who ran the China Center for Energy Economics Research at Xiamen University and advised the Chinese government on energy policy, said: "Sinopec winning engineering work in the U.S. was important to establishing itself as a global brand." He believed that the moving up the U.S. value chain would continue, and that Chinese oil majors such as Sinopec could establish retail gas stations in the U.S. in the next few years. ${ }^{38}$

However, the reality is harsh. During the past two years, SEG was not able to build the plants in Medicine Bow successfully due to various reasons. On February 28, 2014, Sinopec Engineering Group said it had received written notice from Fuel \& Power LLC purporting to terminate the three agreements from 2012. Jiming Zou, a Moody's analyst said, "Although we don't expect major impact on Sinopec Engineering Group's business operations and financial profile, the incident will have a negative impact on its plans to expand into overseas markets." 39

\section{CNOOC}

\subsection{A. An Attempted Acquisition of Unocal and Interventions from U.S. Congress}

\footnotetext{
33 "Fiscal Year 2013 EPA Enforcement and Compliance Annual Results", the Office of Enforcement and Compliance Assurance U.S. Environmental Protection Agency, January 13, 2013.

34 "International Labor Comparison", U.S. Bureau of Labor Statistics, June 7, 2013.

35 "China National Offshore Oil Corporation", Lobbying Database, Center for Responsive Politics, 2014

${ }^{36}$ Qiang Wang, “中海油 : 第一次推开了世界的窗”, Sohu Chinese News, December 21, 2005.

${ }^{37}$ Brian Spegele, "China's Sinopec Moves Into Small U.S. Town", The Wall Street Journal, November 5, 2012.

${ }^{38}$ Brian Spegele, "China's Sinopec Moves Into Small U.S. Town", The Wall Street Journal, November 5, 2012.

${ }^{39}$ Ibid.
} 
China National Offshore Oil Corporation is the third largest oil company in China. It is also the largest natural gas supplier in China. In 2006, visiting Chinese President Hu Jintao and Kenyan President Mwai Kibaki witnessed the signing of the oil exploration agreement between Kenya and CNOOC. In 2005, it topped the bid by Chevron Texaco to buy American oil company Unocal Corporation. However, due to the U.S. Congress opposition, its bid did not succeed. CNOOC has been accused of abuses of Human rights in Burma. The campaign group Arakan Oil Watch stated in a report that CNOOC "left behind such a trail of abuses and environmental contamination on Ramree Island that outraged locals attacked their facilities. ${ }^{40}$

The U.S. Congress has great influence on China-U.S. trade and often blames China for human rights issues, the Tibetan issue, and shortcomings of freedom of speech and democracy. Sometimes, U.S. Congressmen's actions are decisive to the success or failure of Chinese companies in the U.S. On June 23, CNOOC announced $\$ 18.5$ billion bid for U.S. oil firm Unocal, higher than Chevron's $\$ 16.5$ billion. ${ }^{41}$ Four days later, Joe Barton, Texas Republican and chairman of the House Energy and Commerce Committee, wrote a letter to President Bush, saying the U.S. is "threatened by China's aggressive tactics to lock up energy supplies around the world that are largely dedicated for their own use." 42

Many U.S. Congressmen believed that CNOOC was manipulated by the Chinese government. CNOOC made a bid of $\$ 18.5$ billion cash among which $\$ 13$ billion are from the Chinese government. They argued the sale of Unocal to CNOOC was not a free market transaction and should be prohibited. Moreover, they stated that the Chinese government prevented American companies from buying similar assets in China. ${ }^{43}$ So, they thought the trade between China and the U.S. was unfair.

On June 30, the House passed H. Res. 344 and H. Amdt. 431. H. Res. 344 called for a thorough review of CNOOC by the Committee on Foreign Investment in the U.S. (CFIUS), while H. Amdt. 431 prohibited use of Treasury funds to approve sale of Unocal to CNOOC. So, on July 2 CNOOC had to quickly file a CFIUS notice. On July 13, Frank Gaffhey Jr., president of the Center for Security Policy, told the House Armed Services Committee that the sale "would have adverse effects on the economic and national security interests of the United States." He also pointed to "the folly of abetting Communist China's effort to acquire more of the world's relatively finite energy resources" and warned of "the larger and ominous Chinese strategic plan of which this purchase is emblematic." ${ }^{44}$ On July 20 , Chevron raised its offer to about $\$ 16.5$ billion; still $\$ 2$ billion lower than CNOOC's bid, which pushed CNOOC to withdraw its bid on August 2. Finally, on August 10, Unocal accept Chevron's offer. ${ }^{45}$

Table 1. Comparison of CNOOC's and chevron's bids. CNOOC and chevron competing for unocal in 2005. ${ }^{46}$

\begin{tabular}{l|l|l}
\hline & CNOOC & Chevron \\
\hline Country & China & The U.S. \\
\hline bid per share & $\$ 67$ & $\$ 60.65$ \\
\hline Total bid & $\$ 18.5$ billion & $\$ 16.5$ \\
\hline Payment methods & Cash & Cash + stock \\
\hline Preferred by Unocal & Yes (because of higher bid) & No (lower bid) \\
\hline Intervention from Congress & Yes & No \\
\hline Final result & Lost & Won \\
\hline
\end{tabular}

\subsection{B. Why was CNOOC Interested in Acquiring American Oil Assets?}

Chinese oil companies are seeking foreign oil assets to transform themselves into world-class oil

${ }^{40}$ William Boot, "Chinese Oil Giant Accused of Human Rights Abuses in Burma", Irrawaddy.org, October 24, 2008.

${ }^{41}$ Edward Iwata, "Chinese takeover bid for Unocal up in air", USA Today, July 14, 2005.

${ }^{42}$ Paul Bluestein, "Many Oil Experts Unconcerned Over China Unocal Bid", The Washington Post, July 1, 2005.

${ }^{43}$ Ben White, "Chinese Drop Bid to Buy U.S. Oil Firm", The Washington Post, August 3, 2005.

${ }^{44}$ James A. Dorn, "U.S.-China Relations in the Wake of CNOOC", Policy Analysis, No. 553, November 2, 2005.

${ }^{45}$ Dick K. Nato, James K. Jackson, Wayne M. Morrison, etc. "China and the CNOOC Bid for Unocal: Issues for Congress", CRS Report for Congress, February 27, 2006.

${ }^{46}$ Data is based on Edward Iwata, "Chinese takeover bid for Unocal up in air", USA Today, July 14, 2005. 
companies. Former CNOOC general manger Liucheng Wei used a soccer analogy to make that point, arguing that "China's oil companies cannot just play in the domestic league. We should also compete in the World Cup." ${ }^{47}$ Compared to purchasing oil assets in Africa or in the Middle East, acquiring American oil companies have the following advantages. First, China's oil companies can gain technical expertise. One objective of CNOOC's bid for Unocal was to gain deep-water exploration and production capacity. Likewise, its acquisition of a stake in Canada's MEG Energy was said to be targeted at securing advanced oil sands extraction technology. ${ }^{48}$ Second, China's oil companies can learn large project management skills from American oil companies. Compared to Western oil giants like ExxonMobil, BP, and Shell, China's oil companies are latecomers to the international oil business and have less experience in "executing complex projects that involve employing cutting-edge technology, arranging huge financing packages, managing environmental impacts, and finishing on time and on budget." ${ }^{49}$ Third, China was invaded by a group of Western countries in the 19th centuries, such as the two Opium Wars and Boxing Rebellion. Today, still many Chinese people feel that China is a victim of Western powers. They also feel sympathy for Africa which was colonized by Europeans for hundreds of years. Therefore, buying oil companies in America can make them feel more proud of China's rise than doing so in Africa. In the 1980s, when Japanese firms made purchases in America, nationalist sentiment also arose in Japan.

\section{Barriers for Chinese State-owned Oil Companies to Enter the U.S.}

\section{Market}

\subsection{A. The Committee on Foreign Investment in the United States (CFIUS)}

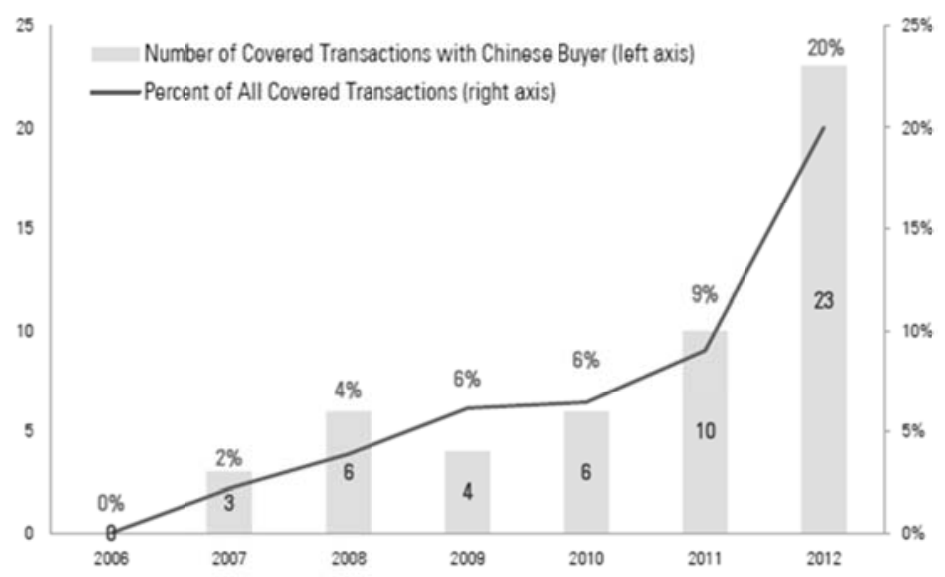

Source: CFIUS Annual Report to Congress, Public Version

Figure 2. CFIUS-covered transactions led by a Chinese buyer, 2006-2012

When CFIUS was established in 1975, it chiefly targeted at Japanese companies, because Japan was then an economic threat to the U.S. Today, Chinese companies replaced Japanese companies and are easily subject to be investigated by CFIUS. Figure 2 shows that the numbers of CFIUS-covered transactions led by a Chinese buyer has been increased rapidly since 2006. In 2007, only $2 \%$ of transactions with Chinese buyers were investigated by CFIUS. In 2012, it rose up to $20 \%$. In other words, one fifth of Chinese investments in the U.S. were challenged by CFIUS in 2012. In the meantime,

\footnotetext{
${ }^{47}$ Erica S. Downs, "Who's Afraid of China's Oil Companies", in Energy Security edited by Carlos Pascual and Jonathan Elkind (Brookings Institution Press, 2010).

${ }^{48}$ Erica S. Downs, "Who's Afraid of China's Oil Companies", in Energy Security edited by Carlos Pascual and Jonathan Elkind (Brookings Institution Press, 2010).

${ }^{49}$ Ibid.
} 
CNN conducted a survey which argued that "most Americans want U.S. leaders to be tough with China on trade and economic issues." ${ }^{50}$ This is not a good signal for the long-term development of China-U.S. trade. With increasing economic conflicts between China and the U.S., CFIUS's status in international business has become much more important than ever before. Thus, in this section I will probe into CFIUS and several important regulations that CFIUS has used to block foreign Mergers \& Acquisitions (M\&A) in the U.S.

CFIUS is probably a little known government agency in the U.S. Reuters called it "the mysterious agency that can block a global merger." In the past few years, companies from China, Russia, Europe and Japan were snatching up U.S. firms which have exposed CFIUS more to media reports. ${ }^{51}$

Although U.S. Congress has the right to speak and suggest, CFIUS is still independent from Congress and answers directly to the President. On its official website, CFIUS defined itself as:

An inter-agency committee authorized to review transactions that could result in control of

a U.S. business by a foreign person ("covered transactions"), in order to determine the

effect of such transactions on the national security of the United States. ${ }^{52}$

CFIUS has its origin back to the Cold War as the Executive Branch of the U.S. government's "economic kill-switch" for FDI. ${ }^{53}$ In 1975, it was established by President Gerald Ford under the Executive Order 11858. At the section 1 of the Executive Order 11858, it reads: "International investment in the U.S. promotes economic growth, productivity, competitiveness, and job creation. It is the policy of the U.S. to support unequivocally such investment, consistent with the protestation of the national security.....there is hereby established the committee on Foreign Investment in the U.S." 54

In addition, the Executive Order 11858 also stated that CFIUS would have "primary continuing responsibility within the Executive Branch for monitoring the impact of foreign investment in the United States, both direct and portfolio, and for coordinating the implementation of United States policy on such investment." ${ }^{55}$ To implement this mandate, CFIUS was directed to:

1. Arrange for the preparation of analyses of trends and significant developments in foreign investments in the United States,

2. Provide guidance on arrangements with foreign governments for advance consultations on prospective major foreign governmental investments in the United States,

3. Review investments in the United States which, in the judgment of the Committee, might have major implications for United States national interests,

4. Consider proposals for new legislation or regulations relating to foreign investment as may appear necessary. ${ }^{56}$

Apparently, when CFIUS was established in mid 1970s, its major target was not Chinese companies, because China was then a closed economy under Mao. Actually, the establishment of CFIUS was a response to the rising Japanese companies in the 1970s and 1980s. For instance, in 1983, a Japanese firm sought to acquire a U.S. specialty steel producer. The steel was used in making military aircraft. So, the Department of Defense and CFIUS stepped in investigation and finally forced the Japanese firm to withdraw its offer. ${ }^{57}$

Over the past decade, U.S. media reports have downplayed the competition and acquisitions from Japanese companies, and highlighted the case of Dubai Ports World in 2006 and several purchases by Chinese companies. There are several reasons for this shift. First, 9/11 changed U.S. foreign policies. The Dubai Ports World Controversy in 2006 is a good example to show how terrorism concerns during the Bush Administration determined the failure or success of foreign investment in the U.S. Second, Japan was once a threat to the U.S., but it has declined since the 1990s. Due to its stagnant economy; Japan has slowed down its speed in overseas merging and acquisition ( $\mathrm{M} \& \mathrm{~A}$ ). Japan is even regarded

\footnotetext{
${ }^{50}$ Charles Riley, "Americans: China Is An Economic Threat", CNNMoney, September 19, 2012.

${ }^{51}$ Jill Priluck, "The Mysterious Agency That Can Block A Global Merger", Reuters, July 8, 2013.

${ }^{52}$ http://www.treasury.gov/resource-center/international/Pages/Committee-on-Foreign-Investment-in-US.aspx

${ }^{53}$ David C. Hoyt, "The Geoeconomic role of CFIUS in U.S-Sino Relations", CSPC Fellows Review, 2011.

${ }^{54}$ Executive Order 11858, U.S. Treasury.

${ }^{55}$ David C. Hoyt, "The Geoeconomic role of CFIUS in U.S-Sino Relations", CSPC Fellows Review, 2011.

${ }^{56}$ Ibid.

${ }^{57}$ James K. Jackson, "Congressional Research Service-The The Committee on Foreign Investment in the United States (CFIUS)", March 6, 2014.
} 
as America's "best ally in Asia." Today, both American public and government no longer think Japan is a competitor to U.S. By contrast, they view China and the Middle East as major threats. The pivot of U.S. foreign policy was shifted to the Middle East during the Bush Administration and now is being shifted to the Asia-Pacific region. ${ }^{58}$ Third, China's communist regime makes the U.S. public more afraid of Chinese companies than Japanese ones. Many Americans still hold a negative image toward China. A CNN Opinion Research Corporation Poll conducted in 2009 found that $71 \%$ of Americans considered China to be an economic threat; two-thirds saw China as a source of unfair competition, and $51 \%$ regarded it as a military threat. ${ }^{59}$

\subsection{B. Another Barrier to Market Entry: Anti-China Interest Groups in the U.S.}

The case of Dubai Ports World showed that American interest groups have a great deal of leverage on U.S. politics. In October 2005, Dubai World, a company in United Arab Emirates, attempted to acquire the right of managing businesses in six U.S. seaports. Eller\& Company, a U.S. firm, opposed this sale and thus hired semi-retired lobbyist Joe Muldoon to persuade Congress to block the deal. Muldoon got support from Democratic New York Senator Charles E. Schumer and an Associated Press reporter who put this deal in the national spotlight ${ }^{60}$ Finally, Dubai Ports World failed to shrug off concern of terrorism and had to sell the operations to a U.S. entity. According to The Washington Times, "Intelligence and security officials opposed to the deal with Dubai Ports World said ports are vulnerable to the entry of terrorists or illicit weapons because of the large number of containers that enter U.S. territory, regardless of who manages them." ${ }^{11}$

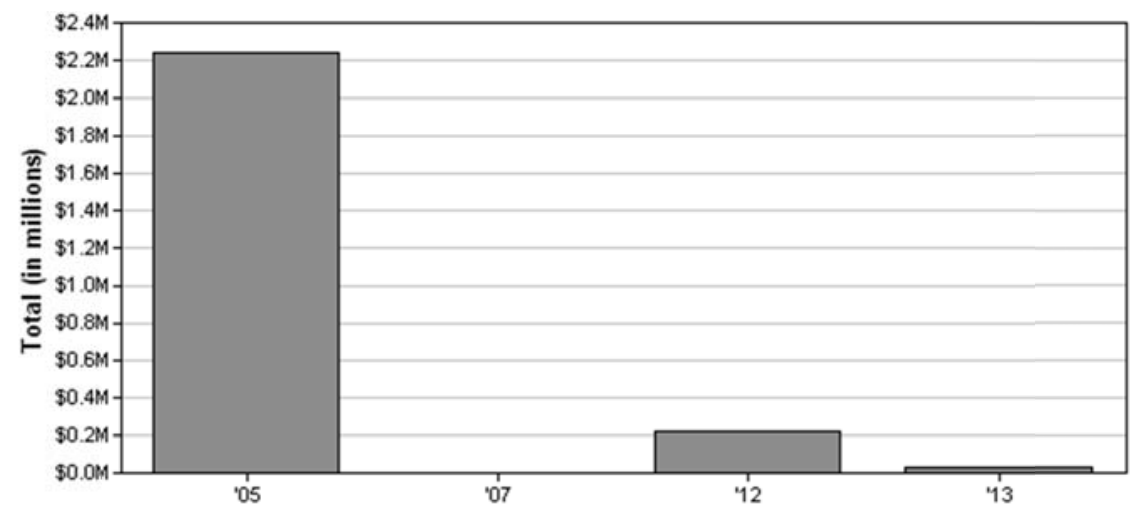

Figure 3. Annual lobbying by China national offshore oil corporation ${ }^{62}$

Unlike the case of Dubai Ports, American interest groups do not associate the purchases by Chinese investor with terrorism. Instead, they blame China for its communist regime, suppression, human rights, unfair trade and more. The anti-China interest groups in the U.S. are strong, including organizations (Labor Union, Human Rights Watch), social media, internet, blogosphere and celebrities. But, there are also pro-China interest groups in America like the US-China Business Council and lobbyists hired by Chinese companies. They compete to influence the Congressional decisions on China. For instance, Figure 3 shows that in 2005 when CNNOC attempted to purchase Unocal, it spent more than $\$ 2.2$ million on lobbying. CNNOC hired Akin Gump Strauss Hauer \& Feld, one lobbying firm in Texas, to assist its purchase. Immediately, Akin Gump Strauss Hauer \& Feld drew criticism from anti-China politicians. On July 12, 2005, Rep. Frank Wolf, R-Va., a member of the Congresisional China Caucus,

\footnotetext{
${ }^{58}$ Ian Bremmer, "U.S. Needs Japan As Its Best Ally in Asia", Financial Times, September, 9, 2012.

${ }^{59}$ Friedrich Wu, Lim Siok Hoon, and Yuzhu Zhang, "Dos and Don'ts for Chinese Companies Investing in the United States: Lessons From Huawei and Haier", in Thunderbird International Business Review, New York: Wiley, 2011.

${ }^{60}$ Peter Overby, "Lobbyist's Last-Minute Bid Set Off Ports Controversy", NPR, March 8, 2006.

61 "Security fears about infiltration by terrorists", The Washington Times, February 22, 2006.

62 "China National Offshore Oil Corporation", Lobbying Database, Center for Responsive Pollitics, 2014.
} 
sent a strongly worded letter to Akin Gump's lobbyists questioning their representation of CNOOC. "When I noted that CNOOC was one of your newest clients, I immediately thought, 'Is there no bright line to separate who the lobbyists in Washington will or will not represent?" "63

An interest group has many names, such as "special interest", "pressure group", "advocacy group", and "lobby group". However, these are "negatively charged terms, each implying unsavory tactics or a lack of a concern for a broader public interest." ${ }^{4}$ A neutral term should be interest group. According to opensecrets.org, there are 12,278 lobbyists in the U.S. by the end of $2013 .{ }^{65}$ Some of them are very influential and can affect America's China policies by lobbying Congress, such as The American Federation of Labor and Congress of Industrial Organizations (AFL-CIO), International Brotherhood of Teamsters; and the National Textile Association all of which were against free trade with China and blamed the Chinese government for violating human rights.

Anti-China interest groups have actively attended congressional committee hearings. For example, in May 1993, there was a hearing held in the House of Representatives. The American Federation of Labor and Congress of Industrial Organizations (AFL-CIO) expressed their opposition against the extended most-favored-nation treatment to China. AFL-CIO used the strategy of either-or choice. It pushed industry and commerce lobbyists to choose "either conscience or profit." The AFL-CIO asked, "Aren't democracy, justice and basic human rights more valuable than those profits gained by exploiting one billion Chinese people?"66

Anti-China interest groups have carried out large-scale lobbying activities of members of U.S. Congress, especially those conservative congressmen from the eastern states with textile firms. They collaborated and proposed cancelling most-favored-nation treatment to China. They put forward separate Sino-US trade bills and demanded mandatory restrictions on Chinese exports to the United States. Under the support of anti-China groups, in April 1990, Massachusetts Democratic representative Barney Frank proposed a bill that cut half of China's textile and garment exports to America. In 1991, Congressman Holmes and Gilman (Republicans from New York) proposed a bill that stipulates: ban on U.S. citizens investing foreign penal facilities, and American companies and trade union have the right to sue penal importer and may ask for three times of compensation for loss. ${ }^{67}$ This bill includes additional terms against Chinese export. Under this bill, American companies must prove that the products they are imported from China are not made by Chinese prisoners. The amount of the punishment to offenders is high enough for all importers.

Anti-china interest groups continuously notified Congressmen and the Customs Administration of suspicious Chinese products made by prisoners, forcing the U.S. Customs officers to conduct compulsory examination on some Chinese products. ${ }^{68}$ In addition, anti-China interest groups communicated each other in information, mutually aided each other and coordinated in lobby actions. For instance, AFLCIO provided Laogai Research Foundation in California a large amount of financial aid. Laogai Research Foundation helped AFL-CIO to collect relevant proof of Chinese exporting products made in forced labor camps. Besides, AFL-CIO aided some human rights organization to supervise China's human rights situation. AFL-CIO leaders also held positions in human rights organizations at the same time, and helped planning activities against most-favored-nation treatment to China. ${ }^{69}$

Based on all, table 2 is created to summarize the strategies adopted by anti-China interest groups. Actually, anti-China sentiment and Anti-Americanism both exist in the U.S. and China, respectively. Nearly 130 years ago, the U.S. approved the 1882 Chinese Exclusion Act, which explicitly rejected Chinese immigrants for six decades because of their race. Until recently U.S. Senate did not apologize. ${ }^{70}$ In China, anti-American sentiments emerged in 1999 when the Chinese Embassy in Yugoslavia was

\footnotetext{
${ }^{63}$ Marina Walker Guevara, "China Steps Up Its Lobbying Game", The Center for Public Integrity, September 13, 2005.

${ }^{64}$ Ronald J. Hrebenar, Interest Group Politics in America (M.E. Sharpe, 1997).

65 "Number of Lobbyists", Lobbying Database, Center for Responsive Politics, 2014.

${ }^{66}$ Yong Wang, "American Interest Group's Impact on U.S. China Policy," American Studies (Chinese), 1998.

${ }^{67}$ Ibid.

${ }^{68}$ Shujie Leng, "Made in China - But Was it Made in a Prison?" NPR, March 29, 2014.

69 "International Trade Report", November 27, 1991.

${ }^{70}$ Matt O’Brien, "U.S. Senate Apologizes for Decades of Anti-Chinese Discrimination", Contra Costa Times, October 7, 2011.
} 
bombed by U.S. Air Force. Thousands of Beijing residents and college students protested in front of the U.S. Embassy in Beijing. Some of them even threw stones to KFC and McDonald's.

Table 2. Tactics used by U.S. Anti-China interest groups

\begin{tabular}{l|l}
\hline & Tactics \\
\hline & $\begin{array}{l}\text { 1. Provide broad media coverage of Tiananmen incident in 1989. They blame trade interest } \\
\text { groups. "Merely pursue money instead of human rights and conscience." } \\
\text { 2. Carry out large-scale lobbying activities and cooperate with conservative congressmen } \\
\text { from Eastern states harmed by textile imports. }\end{array}$ \\
$\begin{array}{l}\text { Anti-China } \\
\text { Interest Groups } \\
\text { made by prisoners). }\end{array}$ \\
$\begin{array}{l}\text { 4. Anti-China interest groups communicate with each other in the information, mutually } \\
\text { support each other in funding, and coordinate in lobbying actions. } \\
\text { 5. Influence public opinion on China, e.g. cyber-security, oil industry and U.S. national } \\
\text { security, Shuanghui's purchase of Smithfield Foods and food safety. } \\
\text { 6. Protect American labors (against exporting jobs to China) and win support from the U.S. } \\
\text { general public. }\end{array}$ \\
\hline
\end{tabular}

\subsection{Chinese Oil Companies' Own Weaknesses}

The causes of Chinese oil companies' failures in the U.S. are complex. We cannot solely blame U.S. Anti-China interest groups. Chinese oil companies' own weaknesses should also be examined. There are at least three major weaknesses of Chinese oil companies. First, Chinese national oil companies do not have mature business strategies for brand-building. For example, both Chinese auto and oil companies have tried entering the U.S. market for years. However, they still do not have a clear guiding ideology on how to win support from American consumers. When it comes to foreign brands, average American consumers can easily name some Japanese or Korean brands, such as Nissan, Toyota, LG, and Samsung. They never heard of BYD (Build Your Dream), a Chinese auto firm that is attempting to pursue the American consumers. BYD had planned to sell its E6 electric hatchbacks in the U.S. by the end of 2010. But, it did not succeed. Stella Li, the senior vice-president in charge of the company's US business, said: "Back then, we had passion, but we had no brand, no history, no capital and no competitive advantage." ${ }^{71}$ Like BYD, the three major Chinese oil companies currently also lack long-term development plans in the U.S., and their negative images to the U.S. government and public will not be improved in a short time.

At the same time, the management of Chinese state-companies' overseas branches is flawed. Some parent companies did not give overseas branches enough autonomy in operation, so they missed some good business opportunities. And, some parent companies just took laissez-faire attitudes toward their overseas subsidiaries, so the overseas subsidiaries were not well regulated and supervised. For example, recently, PetroChina's former Indonesia chief Zhigang Wei was under investigation. ${ }^{72}$ He was accused of buying poor-quality oil fields from Indonesia at unreasonable high prices. Undoubtedly, in the authoritarian regime, corruption is always a big disadvantage of Chinese national oil companies, which leads to non-transparency of decisions and individual leaders' expropriation of the state-owned assets.

Second, Chinese national oil companies face great pressure from domestic energy demand and domestic criticism. Due to its huge population and moderate oil reserves, China's oil consumption per capita is much lower than the world average. ${ }^{73}$ With fast economic development, the Chinese are hungry for world oil, which has imposed great pressure on Chinese national oil companies. Because Chinese national oil companies are supported by the Chinese government and a large amount of their capital is

\footnotetext{
${ }^{71}$ Bloomberg in Beijing and Shanghai, "BYD Plans to Launch into US Market Next Year", South China Morning Post, January 8, 2014.

${ }^{72}$ Charlie Zhu and Chen Aizhu, "PetroChina's Former Indonesia Chief under Investigation", Reuters, October 16, 2013.

73 "Oil Consumption Per Capita", Index Mundi, January 1, 2012.
} 
from Chinese people's taxes. If they make any mistake overseas, they might face fierce criticism from both Chinese public and government.

Third, Chinese national oil companies have an incomplete understanding of non-Eastern Asian cultures. For example, George Feng and Xianzhong Mu's article meticulously exams what cultural challenges are Chinese oil companies facing in Africa and what strategies should they take. According to the authors, Chinese oil companies' overseas management was challenged by miscommunication, working habits, religions, orientation and coexistence. ${ }^{74}$ While the majority of Chinese people today are atheists, people in Africa, the Middle East and the U.S. have beliefs either in Islam, Judaism or Christianity. For example, in the U.S. many stores are closed and there is less traffic on Sunday, because people go to churches. In China, Sunday is probably the best day for business. In order to make more money, some Chinese companies even require employees to work on Sunday, which is unacceptable to some Africans and Americans.

\subsection{The U.S. Urged China to Reform Its State-Owned Enterprises}

During the 1980s and 1990s, the Taiwan issue was probably the major concern between China and the U.S. However, since 2001 economic issues have topped the Taiwan issue in Sino-U.S. relations. The Obama Administration is continuously urging China to further reform itself, including the RMB exchange rate with the dollar, state-owned banks and enterprises, and trade barriers. The U.S. believes that China's state-owned companies still compete with a range of unfair advantages in the Chinese and global markets. For example, China's financial system is still dominated by state-owned banks, who favor lending to large state-owned companies like PetroChina and Sinopec. In addition, the state-owned companies' implicit backing by the Chinese government discourages private firms' entry and expansion. In a meeting at the Commonwealth Club of California, U.S. Treasury Secretary Timothy F. Geithner argued:

If China's state enterprises want to be treated like commercial enterprises by the rest of the world, they need to act more like commercial enterprises, including by paying marketbased dividends to their shareholders and making their corporate governance and finances less opaque. ${ }^{75}$

Geithner seems to favor China's private companies more than the state-owned ones. When he visited Beijing in 2012, he said: "China must rely more on innovation by private companies rather than capacity expansion by state owned enterprise, with an economy more open to competition from foreign firms, and with a more modern financial system." ${ }^{\prime 6}$ Indeed, the U.S. is more afraid of China's stateowned companies which are often related to sensitive sectors like military, telecommunication, energy and banking.

During Geithner's visit to Beijing in 2012, he also slammed the Chinese government's subsidies to state-owned companies. To his surprise, the new China leadership seems to be more cooperative than previous ones. For the first time, according to senior American officials, Chinese negotiators said they would commit to removing advantageous financing and regulatory conditions to state-owned enterprises. The Chinese officials had also agreed to raise foreign firms' stake in join securities ventures. ${ }^{77}$ As a return of favor, in 2013 the U.S. and Canadian government approved the sale of Nexen to CNOOC, which failed in acquiring U.S. oil firm Unocal in 2005.

\subsection{E. China's Rising Military Makes It More Difficult for Chinese Companies to Obtain U.S. Oil Assets}

In the spring of 2006, Chinese President $\mathrm{Hu}$ visited Washington and conducted a tough formal talk with his counterpart, George W. Bush. The talk covered many subjects and urgent issues, such as the rebuilding of Iraq; anti-terrorism; the global financial system; the U.S. debt and China-U.S. trade;

\footnotetext{
${ }^{74}$ George Feng and Xianzhong Mu: "Cultural Challenges to Chinese Oil Companies in Africa and Their Strategies", Energy Policy, vol. 38, issue 11, 2010.

75 "Remarks by Secretary Geithner at the Commonwealth Club of California", April 26, 2012.

76 "Remarks by Secretary Geithner at the Close of the Fourth Strategic and Economic Dialogue", May 4, 2012.

${ }^{77}$ Annie Lowrey, "U.S. Stresses Concessions from China", The New York Times, May 32012.
} 
human rights; and definitely the issue of oil. Hu felt uncomfortable with this visit as Chinese Falun Gong protestor heckled him for several minutes on the White House lawn and besides a White House announcer mixed up China's formal sovereign name (People's Republic of China) with the name preferred by the Nationalist government on Taiwan (Republic of China). By contrast, Hu immediately left for Saudi Arabia after his rash farewell to D.C. and had a greatly cozy atmosphere in Riyadh with the Saudi royal family. Later, it seems that Hu's Arabian sojourn piqued interest in the United States. ${ }^{78}$ Americans seem to be unhappy as the Chinese and Saudis signed new oil contracts. To some extent, the U.S., no matter its politicians or the general public, is getting more and more cautious of the closer relationship between China and the Middle East.

The increasing Chinese oil demand makes China much more nervous about the oil supply security as the U.S. power, particularly the American navy, is globally present and poses a potential threat to China's maritime oil transportation. Based on this rationale, the Chinese are speeding up their military strategy transformation - that is, from the land to the sea. According to Jon Alterman and John Garver, Sino-American conflict in the Middle East could cut China off from access to energy, since the U.S. controls the sea lanes on which oil to China travels. ${ }^{79}$

Traditionally, China adopts the strategy of "watching the tigers fight", which comes from an old Chinese saying. This strategy fairly characterizes China's approach to U.S. policy in the Middle East. Partly this is because the Chinese tend to believe that the grandiose ambitions of the United States to control the Middle East and its oil will not succeed in any case. ${ }^{80}$ In other words, China is not willing to join the fighting in this region. Instead China prefers to free-ride on the U.S. If America's efforts to stabilize the Middle East fail, China will probably not step in. Besides, since Deng Xiaoping, China has always kept in mind that economic development is the top national priority. The Chinese seems to be good at learning lessons from the ancient wisdom, such as "Gao Zhu Qiang, Guang Ji Niang, Huan Cheng Wang," which means "build tall walls, store grains, and claim the throne later." Therefore, the land-defensive strategy has dominated China's military strategy over the past several decades.

The problem is the conflict between the rising oil demand and unmatched navy power. How can China solve the problem? The Chinese media, general public and decision-makers in recent years seem to embrace Mahan's sea power theory warmly. ${ }^{81}$ They call for a transformation of China's military strategy, from land to sea. If we look at several indicators, we will find that China's increasing oil demand is unprecedented. First, China is the second in oil-importing nations, probably become the first in next one or two decades. Oil fuel the rapid economic growth. Once the engine of Chinese economy started, it is difficult to stop or slow it in recent years. Second, China's middle class is growing as more Chinese are getting richer. The young Chinese middle class are well educated and to some extent are also influenced by Western values and life styles. They are eager to buy nice cars with larger consumption. This is also rooted in Chinese culture, the culture of face. Owning a new car, particularly an American or German car, make them not lose face. It is reported that China ranks the top by motor vehicle production in 2010. Third, China is said to be the second largest manufacturing country in terms of Nominal GDP and the first in terms of PPP GPD. ${ }^{82}$ These indicators all suggest that China's economy is fueled and sustained largely by energy, particularly oil. If there is any emergency of oil security, China will suffer greatly, let alone face war with other major powers.

In order to secure China's maritime oil security, in recent years China has diversified the oil sources. Table 3 shows that China has purchased oil assets in regions beyond the Middle East.

\footnotetext{
${ }^{78}$ Jon B. Alterman and John W. Garver, The Vital Triangle: China, the United States, and the Middle East, (CSIS, 2008).

${ }^{79}$ Ibid.

${ }^{80}$ Jon B. Alterman and John W. Garver, The Vital Triangle: China, The United States, And The Middle East, (CSIS, 2008).

${ }^{81}$ James R. Holmes and Toshi Yoshihara, Chinese Naval Strategy in the 21st Century: The Turn to Mahan, (Routledge, 2007).

${ }^{82}$ Data is based on CIA Fact book and Wikipedia.
} 
Table 3. Large merger and acquisition deals by China's state-owned oil firms ${ }^{83}$

\begin{tabular}{l|l|l|l|l}
\hline Company & Date & Country & Assets & Price (US\$ millions) \\
\hline Sinopec & Dec 08 & Syria & Tanganyika Oil & 2,000 \\
\hline CNPC & Nov 08 & Iraq & al-Ahdab field & 2,900 \\
\hline Sinopec & Jun 08 & Australia & AED Oil & 561 \\
\hline Sinopec & Dec 07 & Iran & Yadavaran field & 2,000 \\
\hline Sinopec & Nov 06 & Russia & Udmurtneft & 3,500 \\
\hline Sinopec & May 06 & Angola & Blocks 17 and 18 & 2,400 \\
\hline CNOOC & Jan 06 & Nigeria & OML 130 & 2,300 \\
\hline CNPC & Oct 05 & Kazakhstan & PetroKazakhstan & 4,000 \\
\hline
\end{tabular}

Also, China speeds up transforming itself from a land power to a sea power. China's first aircraft carrier was launched in 2012 and it was reported that China is planning to build four more in coming years. ${ }^{84}$ China also sent military cruises to the Indian Ocean and the Eastern African shore to protect its oil tanker ships. China's strengthening military power is a double-edged sword however. On one hand, it protects Chinese oil companies' overseas assets. But, on the other hand, it may foster the 'China Threat' theory in the U.S. and make it more difficult for Chinese companies to obtain U.S. oil assets. Below is the logic that explains the connection between China's rising military and the failures of China's oil companies in the U.S.:

China's rising market demands;

$\rightarrow$

China started to diversify its oil sources, including buying oil assets from oil-rich countries;

$\rightarrow$

With more overseas oil assets purchased, China started to worry about its oil security (because the U.S. controls the international maritime transportation line);

$\rightarrow$

In order to protect overseas oil assets and transportation, China started to strengthen its military power; $\rightarrow$

However, China's rising military power makes the U.S. more nervous, which fosters the "China Threat Theory" in the U.S.

$\rightarrow$

Oppositions to China's purchase of American oil assets by the U.S. public and Congress. China's stateowned companies are easily subject to the CFIUS investigation.

\section{Conclusion}

In summary, this article covers at least five major sections: 1 . An overview of Chinese state-owned oil companies; 2. A detailed discussion of the big three Chinese oil companies in the U.S., 3. The barriers to market entry, including CFIUS, Anti-China interest groups, U.S. Congress and the rule-based society; 4. Chinese oil companies' own weaknesses; and 5 . The impact of China's rising military power on its companies' overseas purchases.

In the overview section, I find that China's state-owned oil companies have grown very fast over the past two decades. Today, they are top ranked in the Global 500. Their fast development is a result of the state-led development. Unlike private Western oil companies, the leaders of Chinese oil companies are usually appointed, promoted or dismissed by the Chinese government. This article also addressed why they have failed in the U.S. market. To sum up, there are at least three barriers to entry in the U.S. The first barrier is CFIUS, as an executive branch committee under the President rather than a

\footnotetext{
${ }^{83}$ Erica S. Downs, "Who's Afraid of China's Oil Companies", in Energy Security edited by Carlos Pascual and Jonathan Elkind (Brookings Institution Press, 2010).

${ }^{84}$ Mike Hoffman, "China Plans to Build 4 Aircraft Carriers", Defense Tech, January 22, 2014.
} 
Congressional entity. The second barrier is the interaction between U.S. Congress and anti-China interest groups, which makes it more difficult for Chinese companies to trade or invest in the U.S. The anti-China interest groups often cite China's problems (e.g. human rights issues, the Tibetan issue, shortage of freedom of speech and more) to affect Congressional decisions on the China-U.S. trade. Third, the U.S. is a rule-based society which is starkly different from the environment where Chinese oil companies grew up.

\section{References}

1. Aoki, Masahiko. The Role of Government in East Asian Economic Development: Comparative Institutional Analysis. Oxford: Oxford University Press, 1998.

2. Balloon, Anthony, Crocker, Thomas and Shrimp, Eric. "Shuanghui Wins CFIUS Approval of Smithfield Acquisition: Company's Careful Approach to U.S. Government Validated." Alston \& Bird LLP, September 2013.

3. Cary, Eve. "Reforming China's State-owned Enterprises," The Diplomat, accessed on August 18, 2014, http://thediplomat.com/2013/06/reforming-chinas-state-owned-enterprises/

4. Jackson, James. "The Committee on Foreign Investment in the United States (CFIUS)," Congressional Research Service, March 6, 2014.

5. Jackson, James K. Congressional Research Service-The Committee on Foreign Investment in the United States (CFIUS), March 6, 2014.

6. Jiang, Shiwei. "Is Bipolarity a sound recipe for world order-as compared to other historically known alternatives." ICD Annual Conference on Cultural Diplomacy in the USA" Options on the Table," Soft Power, Intercultural Dialogue \& the Future of US Foreign Policy. 2013.

7. Li, J., Guisinger, S., "Comparative Business Failures of Foreign-controlled Firms in the United States," Journal of International Business Studies, 22, 2, 199.

8. Rosoff, William L. and Hauer, Akin. "RECENT DEVELOPMENTS IN CHINESE FDI IN THE UNITED STATES", China Forex, June 152013.

9. Sauvant, Karl P. Investing in the United States: Is the U.S. Ready for FDI from China? Edward Elgar Publishing, 2009.

10.Shih, Toh. "State gold miner enters US arena via HK backdoor", South China Morning Post, February 11, 2010.

11.Khan, Aamir Hussain. UNSC's expansion: prospects for change and implications for the regions and the world. Diss. Monterey, California: Naval Postgraduate School, 2015.

12.Shue, Vivienne. The Reach of the State: Sketches of the Chinese Body Politic. CA: Stanford University Press, 1988.

13.Zhang, Yuwei. "The Changing Face of Chinese ODI in the United States," China Daily, January 9, 2014.

14.Zhao, Suisheng. China -U.S. Relations Transformed: Perspectives and Strategic Interactions. New York: Routledge, 2007.

15.Zhou, May. "PetroChina Poised for Expansion," China Daily USA, November 22, 2013.

16.Zhou, Yu. The Inside Story of China's High-tech Industry: Making Silicon Valley in Beijing. Rowman\&Littlefield Publishers, 2007.

17.Zhu, Charlie and Chen, Aizhu. "PetroChina's Former Indonesia Chief under Investigation," Reuters, October 16, 2013.

18.Zhu, Rongji. The Road to Reform 1991-1997, Washington, D.C.: Brookings Institution Press, 2013. 